\title{
Narrativas Históricas no Ensino de Ciências: uma atividade investigativa para os anos iniciais
}

Jose Crispim Macedo Rocha Junior (UESC)

\section{RESUMO-COMUNICAÇÃO ORAL}

A relevância em torno da discussão sobre o Ensino de Ciências é notável atualmente, principalmente quando o assunto é a inserção de elementos históricos e filosóficos da Ciência no contexto de sala de aula. A História e Filosofia da Ciência (HFC) apresenta diversas vertentes e é advogada por centenas de pesquisadores. Assim, este presente trabalho investigará como o uso de Narrativas Históricas inseridas em atividades investigativas podem contribuir para o ensino e aprendizagem de alunos dos anos inicias do Ensino Fundamental. A coleta de dados será feita por meio videogravação e diário; e as informações obtidas serão avaliadas utilizando a metodologia de Análise Textual Discursiva (ATD). Embora ainda não tenha sido concretizado o trabalho em sala de aula, a perspectiva é de que a execução da atividade se aproxime das ideias conclusivas de Briccia e Carvalho (2011), ambas utilizaram elementos históricos da ciência no contexto real de sala de aula no Ensino Médio e perceberam a viabilidade de se ensinar Ciências a partir dessa abordagem. A finalização desta atividade poderá contribuir para incentivar o uso de elementos de HFC no contexto de sala de aula, uma vez que, muitos trabalhos possuem teor teórico e pouco se tem na prática escolar. 